\title{
Human papillomavirus is not associated to non-small cell lung cancer: data from a prospective cross-sectional study
}

\author{
Estela Maria Silva ${ }^{1 \dagger}$, Vânia Sammartino Mariano ${ }^{1 \dagger} \mathbb{D}$, Paula Roberta Aguiar Pastrez ${ }^{1}$, Miguel Cordoba Pinto ${ }^{2}$, \\ Emily Montosa Nunes ${ }^{3}$, Laura Sichero ${ }^{3}$, Luisa Lina Villa, ${ }^{3,4}$, Cristovam Scapulatempo-Neto ${ }^{1,5}$, \\ Kari Juhani Syrjanen ${ }^{5,6}$ and Adhemar Longatto-Filho $1,7,8,9,10^{*}$
}

\begin{abstract}
Background: The pathogenesis of lung cancer is triggered by a combination of genetic and environmental factors, being the tobacco smoke the most important risk factor. Nevertheless, the incidence of lung cancer in non-smokers is gradually increasing, which demands the search for different other etiological factors such as occupational exposure, previous lung disease, diet among others. In the early $80^{\prime}$ s a theory linked specific types of human papillomavirus (HPV) to lung cancer due to morphological similarities of a subset of bronchial squamous cell carcinomas with other HPV-induced cancers. Since then, several studies revealed variable rates of HPV DNA detection. The current study aimed to provide accurate information on the prevalence of HPV DNA in lung cancer.

Methods: Biopsies were collected from 77 newly diagnosed non-small cell lung cancer (NSCLC) patients treated at the Thoracic Oncology Department at Barretos Cancer Hospital. The samples were formalin fixed and paraffin embedded (FFPE), histologic analysis was performed by an experienced pathologist. DNA was extracted from FFPE material using a commercial extraction kit and HPV DNA detection was evaluated by multiplex PCR and HPV16 specific real-time PCR.
\end{abstract}

Results: HPV was not identified in any of the samples analysed (69).

Conclusions: Our data demonstrated a lack of HPV DNA in a series of NSCL cancers.

Keywords: Non-small cell lung cancer, Lung neoplasms, Papillomaviridae, Papillomavirus DNA

\section{Background}

Lung cancer is the major cause of cancer-related death worldwide. The International Agency for Research on Cancer (IARC) estimated 1.8 million new cases for 2016 [1]. Although the pathogenesis of lung cancer is complex and arises due to a combination of genetic and environmental factors [2], tobacco smoke is consensually assumed as the strongest factor associated to this disease development, worldwide [3]. However, epidemiologic

\footnotetext{
*Correspondence: longatto@med.uminho.pt; longatto16@hotmail.com; http://www.icvs.uminho.pt

'Estela Maria Silva and Vânia Sammartino Mariano contributed equally to this work.

${ }^{1}$ Teaching and Research Institute, Molecular Oncology Research Center, Barretos Cancer Hospital - Pio XII Foundation, Barretos, Brazil

${ }^{7}$ Medical Laboratory of Medical Investigation (LIM) 14. Department of

Pathology, Faculty of Medicine, Universidade de São Paulo, São Paulo, Brazil Full list of author information is available at the end of the article
}

data obtained from different geographical regions have revealed that approximately $25 \%$ of all cases of lung cancer are not attributable to tobacco use [4]. Other risk factors have attracted the attention of physicians because the incidence of this disease among non-smokers has increased in the past years [5-7]. Consequently, other etiological factors have been investigated including occupational exposure, previous lung disease, diet, among others [4, 8]. Additional, human papillomavirus (HPV) infection has emerged as a potential etiological agent for certain types of bronchogenic carcinomas. Syrjänen and col. (1979) [9] suggested in the early 80's that oncogenic HPVs could be responsible for lung cancer pathogenesis [10] due to the morphological resemblances within a subset of bronchial squamous cell carcinomas compared with the clinical manifestations of HPVs in the female genital tract $[9,11,12]$. Since then, numerous studies 
have pointed out an inquisitive heterogeneity on HPV DNA detection rates in lung cancers, with the highest rates detected among Asians [13-18]. European studies reported low or no HPV prevalence (0-10\%) compared with the 22\% (4/18) of Asian study. In the latter, HPV16 and HPV18 prevalence were 11.6 and $8.8 \%$, respectively. However, the authors suggested more attention to study design and laboratory detection methods for analyzing this theme [16].

Syrjanen (2012) [19] performed a systematic review and formal meta-analysis of the literature reporting on HPV detection in lung cancer using MEDLINE and Current Contents platforms and found that geographical origin, histopathological types of cancer and HPV detection methods were not significant co-variates accounting for the heterogeneity of the HPV prevalence in lung cancer. Related to HPV infection as risk for lung cancer development, in 3,083 cases and 4,328 controls in two retrospective case-control studies and, one prospective nested case-control study, no association was observed between HPV infections and lung cancer development; also, viral oncogenes, HPV antibodies and DNA HPV were not related to lung cancer survival [20].

HPV infection in lung tissue was evaluated by another meta-analysis using the search terms "lung cancer", "human papillomavirus", "HPV" and their combinations and, antagonistically, the results suggested that HPV infection in lung tissue have a strong association with lung cancer development [21]. Another meta-analysis based on PubMed, Ovid and Web of Science to identify case-control studies and cohort studies that detected HPV in lung carcinomas included 30 or more cases published before Feb 28, 2017 and corroborated that HPV16 and HPV18 infection significantly increase the risk of lung cancer [22].

Additionally, a Chinese a study developed to identify the association between HPV positive rate and smoking in lung cancer (LC) patients observed that HPV infections are associated with smoking in LC patients and the association may relate to different regions [23]. Lung cancer study of Brazilian patients, the presence of HPV was detected by PCR followed by genotyping, found HPV in 33 of the 63 samples, and HPV types 16 and 18 were detected with frequencies of $81 \%$ (27/33) and 19\% (6/33), respectively. Also, the expression of the E6 and E7 oncoproteins HPV type specific, evaluated by immunohistochemical, was detected in 28/33 samples and 25/ 33 samples, respectively [24].

Due to discrepancies among the results across the world and previous work from our country, we aimed to provide detailed additional data on the HPV burden in lung cancer by evaluating the prevalence of HPV DNA in samples of non-small cell lung cancer (NSCLC) using a specific method for this. Furthermore, p16 expression was accessed by immunohistochemistry (IHC) to further address if it's immunoexpression could be considered as a surrogate marker of HPV activity in NSCLC specimens.

\section{Materials and methods \\ Inclusion criteria}

Samples were achieved from a prospective analysis of patients submitted to the bronchoscopy admitted at Barretos Cancer Hospital between 2013 and 2015. All biopsies were performed for diagnosis and all the patients (77) were naïve of treatment. Patients with NSCLC diagnosis that agreed to participate were included.

\section{Ethics approval and consent to participate}

Written informed consent was provided by all patients and the study was approved by Barretos Cancer Hospital Ethic Committee (number 920.225).

\section{Patient characteristics}

All 77 patients were subjected to a detailed trained interviewer assisted interview for assessment of demographic, NSCLC risk factors and previous history of HPV infection variables.

\section{Tumor samples}

Tumor samples were obtained by endobronchial and transbronchial biopsies. Specimens were routinely processed for histological diagnosis, HPV testing and for immunohistochemical analysis of p16. Pathologic stages were determined according to the American Joint Committee on Cancer (AJCC) [25], and histological classification according to criteria of the World Health Organization (WHO) [26].

\section{DNA extraction}

Formalin-fixed, paraffin-embedded (FFPE) tumor tissue sections, previously evaluated and delimited by an expert pathologist (CSN), were deparaffinized, and using QIAamp DNA Micro kit (QIAGEN, Hilden, Germany) DNA was extracted according to the manufacturer's recommendations. Briefly, 4-6 $10 \mu \mathrm{m}$ FFPE sections were submitted to deparaffinization with $100 \%$ xylene, followed by washes of ethanol (100, 90, and 50\%) and incubation with DNA extraction buffers overnight.

\section{$\beta$-Globin polymerase chain reaction (PCR)}

All 77 DNA samples were quantified by NanoDrop 2000 (ThermoScientific) and subjected to $\beta$-globin gene amplification using PCO3 (ACACAACTGTGTTCACTAGC $\left.5^{\prime}-3^{\prime}\right)$ and PCO4 (CAACTTCATCCACGTTCACC 5'-3') primers. The amplification of a short fragment of 110 pair base of human $\beta$-globin gene indicates the integrity of 
DNA for subsequent analysis. Only $\beta$-globin positive samples (62) were used for HPV analysis.

\section{HPV analysis}

HPV DNA in lung tumors was independently assessed using two different techniques based on real-time PCR. The first one consisted of TaqMan singleplex based type-specific real-time PCR targeting the E7 region of HPV 16 type using specific TaqMan probe (5' - 6FAMCAAGCAGAACCGGACAG-MGBNFQ-3') and primers (forward 5'-GATGAAATAGATGGTCCA GC-3' and reverse 5'- GCTTTGTACGCACAACCG AAGC-3') [27]. Among 77 lung samples, 62 were analyzed by this assay and the reaction mixture was prepared as follows: TaqMan Universal PCR Master Mix 1 x (Applied Biosystem, Inc., EUA), $400 \mathrm{nM}$ of each primer, $200 \mathrm{nM}$ TaqMan probe and DNAse/ RNAse free water. PCR amplifications were carried out using $5 \mu \mathrm{L}$ of template DNA in a final volume of $25 \mu \mathrm{L}$ in an ABI Prism 7900HT Fast Real-Time PCR System (Thermo Fisher Scientific, USA). The amplification conditions were as follows: initial denaturation for $10 \mathrm{~min}$ at $95^{\circ} \mathrm{C}$, followed by 40 amplification cycles of $15 \mathrm{~s}$ each at $95^{\circ} \mathrm{C}$ and $1 \mathrm{~min}$ at $60^{\circ} \mathrm{C}$ (annealing-extension step). Each PCR reaction included a negative (water) and a positive control (DNA extracted from CaSki cell line). All samples and controls were tested in duplicate and were considered positive when both replicates amplified in a cycle $<38$.

Additionally, 29 samples were randomly chosen for testing using a type-specific PCR bead-based multiplex genotyping assay that combine multiplex PCR and beadbased Luminex technology (Luminex Corp., Austin, TX, USA) that is able to identify $21 \mathrm{HPV}$ types [28, 29], as previously described [28] and, based on available biological data [30]. Additionally, the assay has a positive control for the quality of the template DNA represented by $\beta$-globin gene primers. PCRs were performed with $10 \mu \mathrm{L}$ of template DNA in a 96 -well format in $25-\mu \mathrm{l} /$ well final reaction volume. HPV multiplex PCR were performed using QIAGEN Multiplex PCR Kit (Qiagen, Dusseldorf, Germany), according to manufacturer's instructions. Each reaction consisted of 45 cycles: $94^{\circ} \mathrm{C}$ for $30 \mathrm{~s}, 63^{\circ} \mathrm{C}$ for $3 \mathrm{~min}$, and $72{ }^{\circ} \mathrm{C}$ for $90 \mathrm{~s}$. The first cycle was preceded by incubation at $95^{\circ} \mathrm{C}$ for $15 \mathrm{~min}$ and the last cycle was extended for $10 \mathrm{~min}$ at $72^{\circ} \mathrm{C}$. PCR negative control consisted of a reaction mix without DNA. Hybridizations were performed according to Schmitt et al. (2006) [31]. For each HPV type-specific probe, the mean fluorescence intensity (MFI) values obtained when no PCR product was added to the hybridization mixture was considered as background. The cutoffs were calculated by adding 5 MFI to 1.1 times the value of the median background. MFI values $>20$ were considered positive.

\section{Immunohistochemistry}

Sections of $4 \mu \mathrm{m}$ containing representative tumour areas were used for IHC, which was performed using Ventana Benchmark ULTRA automated system (Ventana Medical Systems, Inc., Tucson, AZ). Antigen retrieval was performed using cell conditioning 1 buffer $(\mathrm{CC} 1)$ at $95^{\circ} \mathrm{C}$ for $64 \mathrm{~min}$. For detection of immune reaction we used the ultraView Universal DAB Detection Kit polymer amplification system (Ventana Medical Systems, Mannheim, Germany) according to manufacturer's instructions. Mouse monoclonal anti-human antibody against p16INK4A protein, Clone $\mathrm{E} 6 \mathrm{H} 4^{\mathrm{ma}}$, ready for use (Ventana, USA) was used as primary antibody. Samples with strong and diffuse nuclear and cytoplasmic staining in more than $70 \%$ of the cells were considered positive $[25,26]$. All slides were analyzed by two observers (CSN and ALF) who revised discordant cases for achieving consensus. A cervical adenocarcinoma was used as a positive control for p16 staining and negative controls were obtained by omitting the primary antibodies $[32,33]$.

\section{Statistical analyses}

Frequencies were obtained using the IBM $^{\circ}$ SPSS $^{\circ}$ Statistics 21.0 software for Windows (IBM Corporation, Somers, NY, USA).

\section{Results}

Among 77 samples included in this study, 15 were excluded due to the lack of $\beta$-Globin amplification and 62 were suitable for further analysis: 41 (66.1\%) squamous cell carcinomas (SCC) and 21 (33.9\%) adenocarcinomas. The SCC staging was as follow: $2(3.4 \%)$ stage I, 4 (6.8\%) stage II, 26 (44.1\%) stage III and $27(45.8 \%)$ stage IV. Additionally, 27 tissue samples (51.9\%) were classified as well or moderately differentiated, and 25 $(48.1 \%)$ as poorly differentiated. Most patients were male $(n=47,75.8 \%)$, married $(n=40,64.5 \%)$, and $54(87.1 \%)$ have lived in rural area. As a consequence, 21 (33.9\%) patients were farmer. Further characteristics of the patients included in this study are summarized in Table 1. The immunohistochemical staining of tumor for p16 and Ki-67 are illustrated in Figure 1.

None of the 62 NSCLC samples tested was positive for HPV using any of the techniques. Furthermore, p16 immunoreaction of all NSCLC was analyzed and it was observed positive expression in $10(14,3 \%)$ cases. The analysis of positive cases for the expression of p16 (10/70) in relation to socio-demographic information, lifestyle and clinical-pathological findings showed no statistically significant correlation (Table 2). 
Table 1 General Characteristics of NSCLC patients

\begin{tabular}{|c|c|c|}
\hline Characteristic & $\begin{array}{l}\text { Frequency } \\
(n)\end{array}$ & $\begin{array}{l}\text { Valid } \\
\text { Percent (\%) }\end{array}$ \\
\hline \multicolumn{3}{|l|}{ Alcohol intake } \\
\hline No & 7 & 11.3 \\
\hline Yes & 55 & 88.7 \\
\hline \multicolumn{3}{|c|}{ Smoking habits } \\
\hline No & 9 & 14.5 \\
\hline Yes & 53 & 85.5 \\
\hline \multicolumn{3}{|c|}{ Exposure to pesticide and insecticides } \\
\hline No & 32 & 51.6 \\
\hline Yes & 30 & 48.4 \\
\hline \multicolumn{3}{|c|}{ Exposure to asbestos } \\
\hline No & 45 & 80.4 \\
\hline Yes & 11 & 19.6 \\
\hline \multicolumn{3}{|c|}{ Quantity of sexual partners $^{a}$} \\
\hline $1-10$ & 34 & 56.6 \\
\hline $11-100$ & 22 & 36.6 \\
\hline$>100$ & 4 & 6.7 \\
\hline \multicolumn{3}{|l|}{ Oral sex ${ }^{a}$} \\
\hline No & 42 & 71.2 \\
\hline Yes & 17 & 28.8 \\
\hline \multicolumn{3}{|c|}{ History of Sexually transmitted disease ${ }^{a}$} \\
\hline No & 51 & 83.6 \\
\hline Yes & 10 & 16.4 \\
\hline \multicolumn{3}{|c|}{ History of Genital warts ${ }^{\mathrm{a}}$} \\
\hline No & 57 & 93.4 \\
\hline Yes & 4 & 6.6 \\
\hline Total & 62 & 100 \\
\hline
\end{tabular}

\section{Discussion}

The main goal of this study was to evaluate the presence of HPV DNA in NSCLC. Many contradictory results have been found among the reports published about this issue; the majority of discordances may likely be attributable to the differences in methodology used to identify HPV and the fact that many studies have no control regarding the quality of the samples preservation retrospectively selected for analysis. After all, it is not a surprise that an assertive attention about the real meaning of HPV in lung cancer is currently questionable. We did not find any NSCLC positive sample for HPV DNA among the samples we evaluated, despite the use of a very sensitive methodology we used to identify HPV, and the stringent conditions to preserve the samples prospectively collected, including rigorous control of quality in each step of the study. This final result is in agreement with some results obtained worldwide from different studies groups [34, 35]. Ywakawa et al. [36], e.g., analysed HPV-16, 18 and 33 DNA in 275 lung adenocarcinoma samples using 2 different methodologies (PCR multiplex and nested PCR) and also found no positive samples. Additionally, in another series [37] comprising 196 samples (100 adenocarcinoma and 96 squamous cell carcinoma), using in situ hybridization (ISH) capable of detecting high-risk HPV DNA (16, 18, 31, 33, 35, 39, 45, 51, 52, 56, 58, 68 and 70) no HPV DNA was observed. These data argue against the possible participation of HPV in NSCLC carcinogenesis [36, 37].

On the other hand, some studies have reported correlation between HPV and lung cancer [21]. Syrjänen et al. [38] detected HPV DNA in 4/77 (5.2\%) NSCLC samples, three of which were positive for HPV-16 and one sample for HPV -6 / -16 coinfection, using multiplex PCR (Luminex ${ }^{\odot}$ ). Sarchianaki et al. [2] analysed 100 samples of NSCLC using real-time PCR methodology (GP5 + / GP6 +) and, 19 (19\%) samples tested positive for HPV DNA. In order to genotype the positive samples, LINEAR ARRAY HPV Genotyping (Roche) capable of detecting 37 high and low risk HPV genotypes was also used, and $42.1 \%(8 / 19)$ of the positive samples were HPV-16 [2]. Moreover, Yu et al. [39] analysed 261 samples (107 squamous cell carcinoma, 63 adenocarcinoma and 91 non-tumour samples as control) by realtime PCR and INNO LIPA; 59.8\% (64/107) in SCC, $17.5 \%(11 / 63)$ of the adenocarcinoma samples and $23.1 \%$ in the control samples were positive for HPV DNA. HPV-16 and / or 18 were found in $79.7 \%$ in SCC, $72.7 \%$ in adenocarcinoma and $14.3 \%$ in the control samples [39].

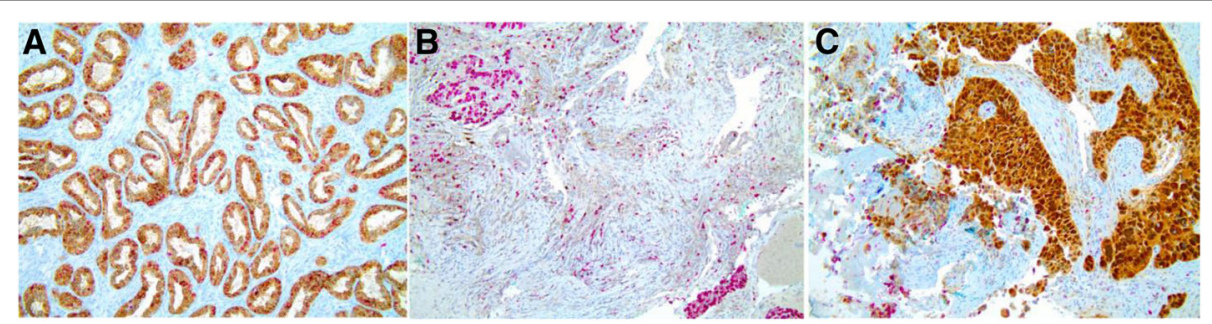

Fig. 1 Immunohistochemical staining of tumor for p16 expression. a Adenocarcinoma cervical used as positive control. b NSCLC sample scored as negative p16 expression. c NSCLC sample considered as positive p16 expression. As cell proliferation nuclear marker was used Ki-67. Magnification: $\times 20$ 
Table 2 Characterization of the case group in relation to the expression of p16 and socio-demographic variables, lifestyle and clinical data. Cancer Hospital of Barretos, January/2013 to October/2015

\begin{tabular}{|c|c|c|c|c|c|c|}
\hline \multirow[t]{3}{*}{ Variable } & \multirow[t]{3}{*}{ Category } & \multicolumn{4}{|c|}{ p16 expression } & \multirow[t]{3}{*}{$\mathrm{p}$} \\
\hline & & \multicolumn{2}{|c|}{ Positive } & \multicolumn{2}{|c|}{ Negative } & \\
\hline & & $n(*)$ & (\%) & $n(*)$ & (\%) & \\
\hline \multirow[t]{2}{*}{ Gender } & Female & 4 & $(40,0)$ & 13 & $(21,7)$ & 0,242 \\
\hline & Male & 6 & $(60,0)$ & 47 & $(78,3)$ & \\
\hline \multirow[t]{2}{*}{ Race } & Não Branco & 3 & $(30,0)$ & 12 & $(20,3)$ & 0,679 \\
\hline & Branco & 7 & $(70,0)$ & 47 & $(79,7)$ & \\
\hline \multirow[t]{2}{*}{ Alcohol intake } & Yes & 8 & $(80,0)$ & 53 & $(88,3)$ & 0,607 \\
\hline & No & 2 & $(20,0)$ & 7 & $(11,7)$ & \\
\hline \multirow[t]{2}{*}{ Smoking habits } & Yes & 5 & $(50,0)$ & 36 & $(60,0)$ & 0,731 \\
\hline & No & 5 & $(50,0)$ & 24 & $(40,0)$ & \\
\hline \multirow[t]{2}{*}{ Histological types } & Squamous cell carcinoma & 6 & $(60,0)$ & 37 & $(61,7)$ & 0,999 \\
\hline & Adenocarcinoma & 4 & $(40,0)$ & 23 & $(38,3)$ & \\
\hline \multirow[t]{2}{*}{ Differentiation Degree } & Well or Moderate & 3 & $(30,0)$ & 25 & $(52,1)$ & 0,301 \\
\hline & Poor & 7 & $(70,0)$ & 23 & $(47,9)$ & \\
\hline \multirow[t]{2}{*}{ T } & $\mathrm{T} 1-\mathrm{T} 2$ & 2 & $(20,0)$ & 12 & $(20,7)$ & 0,999 \\
\hline & $\mathrm{T} 3-\mathrm{T} 4$ & 8 & $(80,0)$ & 46 & $(79,3)$ & \\
\hline \multirow[t]{2}{*}{ N } & No & 1 & $(10,0)$ & 10 & $(17,2)$ & 0,999 \\
\hline & $\mathrm{N}$ positive & 9 & $(90,0)$ & 48 & $(82,8)$ & \\
\hline \multirow[t]{2}{*}{ M } & MO & 4 & $(40,0)$ & 28 & $(48,3)$ & 0,739 \\
\hline & $\mathrm{M} 1$ & 6 & $(60,0)$ & 30 & $(51,7)$ & \\
\hline \multirow[t]{2}{*}{ Stage } & I- II & 0 & $(0,0)$ & 6 & $(10,5)$ & 0,580 \\
\hline & III - IV & 10 & $(100,0)$ & 51 & $(89,5)$ & \\
\hline Total & & 10 & (100) & 60 & (100) & \\
\hline
\end{tabular}

$(*)$ Cases with missing values were excluded from the analysis

$n$ number; TNM staging: a system based on the size and/ or the extension of the primary tumor (T), the number of compromised lymph nodes ( $\mathrm{N}$ ) and the presence of metastasis (M). Fisher's exact test was used. It was considered statistically significant $p<0.05$

Together, these data indicate a wide rate of variation in the frequency of HPV among lung cancers with the highest frequency of virus being reported in East Asian countries, with a prevalence variation of $11.8-55.0 \%$ [16]. Finally, in a recent meta-analysis [40], 46 studies that demonstrated a higher prevalence of HPV in Asian countries $(28.1 \%)$ when compared with European countries (8.4\%) and countries from North and South America (21.3\%), with regional differences between countries being observed. When the analysis was limited to HPV-16 and 18 , which are the HPV types of higher oncogenic risk, a significant higher prevalence was observed in Asia (23.1\%) in relation to Europe (4.4\%) or the Americas (15.6\%). This is interesting because some studies suggest that the heterogeneity in the prevalence of HPV in lung cancer is mainly due to the geographic differences, the different histological types analysed and the different detection methods used [19], besides the sample size, demographic composition of each study and host-specific factors $[14,16]$. There is a consensus among most of the studies that it is necessary to investigate more cases to understand the real role (if any) of HPV in pulmonary carcinogenesis $[14,16,20,37,40]$.

Still in an attempt to explore the relationship of HPV with NSCLC, IHC was performed in NSCLC paraffin samples to evaluate the expression of $\mathrm{p} 16$, a protein considered an indirect marker for HPV infection, since in SCC and adenocarcinoma of uterine cervix and, in a fraction of oropharyngeal squamous cell carcinomas, the overexpression of p16 is strongly related to HPV infection [37]. However, the relationship between p16 expression and NSCLC is not well established [41] and our data were not able to demonstrate the presumed relationship. Chang et al. [37], in addition to the evaluating the presence of HPV DNA, also evaluated the expression of p16 on NSCLC by IHC, and as a result, no correlation between the HPV and p16 expression was determined. Other authors, such as van Boerdonk et al. [42], Bishop et al. [43] and Doxtader et al. [41], presented similar results, with 20 to $30 \%$ of NSCLC, both adenocarcinoma and squamous cell carcinoma, positive for p16 and negative for HPV DNA. In addition, these authors concluded 
that IHQ for p16 cannot be considered a surrogate method for assessing the presence of HPV in lung cancer.

\section{Conclusion}

Our data shows lack of HPV infection in a series of NSCL cancers. The few p16-positive cases are therefore unrelated to HPV. Several reports evaluating the prevalence of HPV DNA are increasing and new evidences with the HPV infection and NSCL coexistence are emerging [40-43]. However, there is still a lack of robust evidences of the possible participation of HPV in NSCLC carcinogenesis [44].

\section{Acknowledgements}

The authors thank the Endoscopy Department of Barretos Cancer Hospital where bronchoscopy were performed.

\section{Authors' contributions}

VSM and ALF wrote the paper and discussed results; EMS, PRAP, MCP, VSM collected samples; CSN and ALF did the p16 reading and interpretation. EMS, PRAP and VSM isolated DNA; EMS, EMN, VSM and LS carried out HPV genotype detection; KJS and ALF designed the study; ALF supervised all experiments performed as principal investigator. LS and LLV discussed an interpreted HPV results and the final text of the manuscript. All participants contributed commentary on and corrected the manuscript. All authors read and approved the final manuscript.

\section{Funding}

This work was funded by Conselho Nacional de Desenvolvimento Científico e Tencnológico (CNPq) [Grants number 401775/2012-7 to ALF; 573799/ 2008-3 to LLV]; Fundação de Amparo à Pesquisa do Estado de São Paulo (FAPESP) [Grants numbers 2014/23414-8 to EMS; 08/57889-1 to LLV].

\section{Availability of data and materials}

All data generated or analyzed during this study are included in this manuscript.

\section{Consent for publication}

Not applicable.

\section{Competing interests}

The authors declare that they have no competing interests.

\section{Author details}

${ }^{1}$ Teaching and Research Institute, Molecular Oncology Research Center, Barretos Cancer Hospital - Pio XII Foundation, Barretos, Brazil. Department of Chest, Barretos Cancer Hospital - Pio XII Foundation, Barretos, Brazil. ${ }^{3}$ Center for Translational Research in Oncology, Instituto do Cancer do Estado de Sao Paulo - ICESP, São Paulo, Brazil. ${ }^{4}$ Department of Radiology and Oncology, School of Medicine, Universidade de São Paulo, São Paulo, Brazil. ${ }^{5}$ Associate Researcher in COI Institute, Rio de Janeiro, Brazil. ${ }^{6}$ Department of Clinical Research - Biohit Oyj, Helsinki, Finland. ${ }^{7}$ Medical Laboratory of Medical Investigation (LIM) 14. Department of Pathology, Faculty of Medicine, Universidade de São Paulo, São Paulo, Brazil. ${ }^{8}$ Research Institute of Life and Health Sciences (ICVS), School of Medicine, University of Minho, Braga, Portugal. ${ }^{9}$ ICVS, 3B's - Associated Laboratory to the Government of Portugal, Braga, Guimarães, Portugal. ${ }^{10}$ Surgical Sciences Research Domain Life and Health Sciences Research Institute (ICVS) School of Medicine, University of Minho, Campus de Gualtar, 4710-057 Braga, Portugal.

Received: 16 January 2019 Accepted: 24 July 2019

Published online: 02 August 2019

\section{References}

1. Ferlay J, Soerjomataram I, Dikshit R, Eser S, Mathers C, Rebelo M, et al. Cancer incidence and mortality worldwide: sources, methods and major patterns in GLOBOCAN 2012. Int J Cancer. 2015;136(5):E359-86.
2. Sarchianaki E, Derdas SP, Ntaoukakis M, Vakonaki E, Lagoudaki ED, Lasithiotaki I, et al. Detection and genotype analysis of human papillomavirus in non-small cell lung cancer patients. Tumour Biol. 2014;35(4):3203-9.

3. Whiteman DC, Wilson LF. The fractions of cancer attributable to modifiable factors: a global review. Cancer Epidemiol. 2016;44:203-21.

4. Malhotra J, Malvezzi M, Negri E, La Vecchia C, Boffetta P. Risk factors for lung cancer worldwide. Eur Respir J. 2016;48(3):889-902.

5. Sagerup CM, Nymoen DA, Halvorsen AR, Lund-Iversen M, Helland A, Brustugun OT. Human papilloma virus detection and typing in 334 lung cancer patients. Acta Oncol. 2014;53(7):952-7.

6. Thun MJ, Henley SJ, Calle EE. Tobacco use and cancer: an epidemiologic perspective for geneticists. Oncogene. 2002;21(48):7307-25.

7. Sun S, Schiller JH, Gazdar AF. Lung cancer in never smokers--a different disease. Nat Rev Cancer. 2007:7(10):778-90.

8. Akhtar N, Bansal JG. Risk factors of lung Cancer in nonsmoker. Curr Probl Cancer. 2017:41(5):328-39.

9. Syrjanen KJ. Morphologic survey of the condylomatous lesions in dysplastic and neoplastic epithelium of the uterine cervix. Arch Gynecol. 1979;227(2):153-61.

10. Syrjanen KJ. Condylomatous changes in neoplastic bronchial epithelium Report of a case. Respiration. 1979;38(5):299-304.

11. Meisels A, Fortin R. Condylomatous lesions of the cervix and vagina. I. Cytologic patterns. Acta Cytol. 1976;20(6):505-9.

12. Syrjanen KJ. Histological and cytological evidence of a condylomatous lesion in association with an invasive carcinoma of uterine cervix. Arch Geschwulstforsch. 1979;49(5):436-43.

13. de Freitas AC, Gurgel AP, de Lima EG. de Franca Sao Marcos B, do Amaral CM. Human papillomavirus and lung cancinogenesis: an overview. J Cancer Res Clin Oncol. 2016;142(12):2415-27.

14. Ragin C, Obikoya-Malomo M, Kim S, Chen Z, Flores-Obando R, Gibbs D, et al. HPV-associated lung cancers: an international pooled analysis. Carcinogenesis. 2014;35(6):1267-75.

15. Klein F, Amin Kotb WF, Petersen I. Incidence of human papilloma virus in lung cancer. Lung Cancer. 2009;65(1):13-8.

16. Srinivasan M, Taioli E, Ragin CC. Human papillomavirus type 16 and 18 in primary lung cancers--a meta-analysis. Carcinogenesis. 2009;30(10):1722-8.

17. Ciotti M, Giuliani L, Ambrogi V, Ronci C, Benedetto A, Mineo TC, et al. Detection and expression of human papillomavirus oncogenes in non-small cell lung cancer. Oncol Rep. 2006;16(1):183-9.

18. Giuliani L, Favalli C, Syrjanen K, Ciotti M. Human papillomavirus infections in lung cancer. Detection of E6 and E7 transcripts and review of the literature. Anticancer Res. 2007;27(4C):2697-704.

19. Syrjanen K. Detection of human papillomavirus in lung cancer: systematic review and meta-analysis. Anticancer Res. 2012;32(8):3235-50.

20. Anantharaman D, Gheit T, Waterboer T, Halec G, Carreira C, Abedi-Ardekani $B$, et al. No causal association identified for human papillomavirus infections in lung cancer. Cancer Res. 2014;74(13):3525-34.

21. Zhai K, Ding J, Shi HZ. HPV and lung cancer risk: a meta-analysis. J Clin Virol. 2015;63:84-90

22. Xiong WM, Xu QP, Li X, Xiao RD, Cai L, He F. The association between human papillomavirus infection and lung cancer: a system review and meta-analysis. Oncotarget. 2017:8(56):96419-32.

23. Zhang R, Chen L, Cui YD, Li G. The association between human papillomavirus infection and smoking, age, gender in lung Cancer patients: a meta-analysis. Iran J Public Health. 2019;48(1):1-8.

24. de Oliveira THA. Do Amaral CM, de Franca Sao Marcos B, Nascimento KCG, de Miranda Rios AC, Quixabeira DCA, et al. presence and activity of HPV in primary lung cancer. J Cancer Res Clin Oncol. 2018;144(12):2367-76.

25. Edge SB, Compton CC. The American joint committee on Cancer: the 7th edition of the AJCC cancer staging manual and the future of TNM. Ann Surg Oncol. 2010;17(6):1471-4

26. Travis WD, Brambilla E, Nicholson AG, Yatabe $Y$, Austin JH, Beasley MB, et al. The 2015 World Health Organization classification of lung tumors: impact of genetic, clinical and radiologic advances since the 2004 classification. J Thorac Oncol. 2015;10(9):1243-60.

27. Walboomers JM, Jacobs MV, Manos MM, Bosch FX, Kummer JA, Shah KV, et al. Human papillomavirus is a necessary cause of invasive cervical cancer worldwide. J Pathol. 1999;189(1):12-9.

28. Gheit T, Billoud G, de Koning MN, Gemignani F, Forslund O, Sylla BS, et al. Development of a sensitive and specific multiplex PCR method combined 
with DNA microarray primer extension to detect Betapapillomavirus types. J Clin Microbiol. 2007;45(8):2537-44.

29. Munoz N, Castellsague X, de Gonzalez AB, Gissmann L. Chapter 1: HPV in the etiology of human cancer. Vaccine. 2006;24(Suppl 3):S3/1-10.

30. Halec G, Schmitt M, Dondog B, Sharkhuu E, Wentzensen N, Gheit T, et al. Biological activity of probable/possible high-risk human papillomavirus types in cervical cancer. Int J Cancer. 2013;132(1):63-71.

31. Schmitt M, Bravo IG, Snijders PJ, Gissmann L, Pawlita M, Waterboer T. Bead-based multiplex genotyping of human papillomaviruses. J Clin Microbiol. 2006;44(2):504-12.

32. Begum S, Gillison ML, Ansari-Lari MA, Shah K, Westra WH. Detection of human papillomavirus in cervical lymph nodes: a highly effective strategy for localizing site of tumor origin. Clin Cancer Res. 2003;9(17):6469-75.

33. Singhi AD, Westra WH. Comparison of human papillomavirus in situ hybridization and p16 immunohistochemistry in the detection of human papillomavirus-associated head and neck cancer based on a prospective clinical experience. Cancer. 2010;116(9):2166-73.

34. Koshiol J, Rotunno M, Gillison ML, Van Doorn LJ, Chaturvedi AK, Tarantini L, et al. Assessment of human papillomavirus in lung tumor tissue. J Natl Cancer Inst. 2011;103(6):501-7.

35. Joh J, Jenson AB, Moore GD, Rezazedeh A, Slone SP, Ghim SJ, et al. Human papillomavirus (HPV) and Merkel cell polyomavirus (MCPyV) in non small cell lung cancer. Exp Mol Pathol. 2010;89(3):222-6.

36. Iwakawa R, Kohno T, Enari M, Kiyono T, Yokota J. Prevalence of human papillomavirus 16/18/33 infection and p53 mutation in lung adenocarcinoma. Cancer Sci. 2010;101(8):1891-6.

37. Chang SY, Keeney M, Law M, Donovan J, Aubry MC, Garcia J. Detection of human papillomavirus in non-small cell carcinoma of the lung. Hum Pathol. 2015;46(11):1592-7.

38. Syrjanen K, Silvoniemi M, Salminen E, Vasankari T, Syrjanen S. Detection of human papillomavirus genotypes in bronchial cancer using sensitive multimetrix assay. Anticancer Res. 2012;32(2):625-31.

39. Yu Y, Yang A, Hu S, Zhang J, Yan H. Significance of human papillomavirus 16/18 infection in association with p53 mutation in lung carcinomas. Clin Respir J. 2013;7(1):27-33.

40. Hasegawa Y, Ando M, Kubo A, Isa S, Yamamoto S, Tsujino K, et al. Human papilloma virus in non-small cell lung cancer in never smokers: a systematic review of the literature. Lung Cancer. 2014;83(1):8-13 Guo L, Liu S, Zhang S, Chen Q, Zhang M, Quan P, Sun X. Human papillomavirus infection as a prognostic marker for lung adenocarcinoma: a systematic review and metaanalysis. Oncotarget. $2017 ; 8(21): 34507-34515$. doi: 10.18632/oncotarget.15671.

41. Doxtader EE, Katzenstein AL. The relationship between p16 expression and high-risk human papillomavirus infection in squamous cell carcinomas from sites other than uterine cervix: a study of 137 cases. Hum Pathol. 2012;43(3): 327-32 Kim Y, Pierce CM, Robinson LA. Impact of viral presence in tumor on gene expression in non-small cell lung cancer. BMC Cancer. 2018;18(1): 843. doi: 10.1186/s12885-018-4748-0.

42. van Boerdonk RA, Daniels JM, Bloemena E, Krijgsman O, Steenbergen RD, Brakenhoff RH, et al. High-risk human papillomavirus-positive lung cancer: molecular evidence for a pattern of pulmonary metastasis. J Thorac Oncol. 2013; 8(6):711-8 Xiong WM, Xu QP, Li X, Xiao RD, Cai L, He F. The association between human papillomavirus infection and lung cancer: a system review and metaanalysis. Oncotarget. 2017;8(56):96419-96432. doi: 10.18632/oncotarget.21682.

43. Bishop JA, Ogawa T, Chang X, Illei PB, Gabrielson E, Pai SI, et al. HPV analysis in distinguishing second primary tumors from lung metastases in patients with head and neck squamous cell carcinoma. Am J Surg Pathol. 2012;36(1): 142-8 Argyri E, Tsimplaki E, Marketos C, Politis G, Panotopoulou E. Investigating the role of human papillomavirus in lung cancer. Papillomavirus Res. 2017;3:7-10. doi: 10.1016/j.pvr.2016.12.002.

44. Kim Y, Pierce CM, Robinson LA. Impact of viral presence in tumor on gene expression in non-small cell lung cancer. BMC Cancer. 2018;18(1):843. https://doi.org/10.1186/s1 2885-018-4748-0.

\section{Publisher's Note}

Springer Nature remains neutral with regard to jurisdictional claims in published maps and institutional affiliations.

\section{Ready to submit your research? Choose BMC and benefit from:}

- fast, convenient online submission

- thorough peer review by experienced researchers in your field

- rapid publication on acceptance

- support for research data, including large and complex data types

- gold Open Access which fosters wider collaboration and increased citations

- maximum visibility for your research: over $100 \mathrm{M}$ website views per year

At BMC, research is always in progress.

Learn more biomedcentral.com/submissions 